\title{
Synthesis and evaluation of the antitumor potential of novel methyl 3-(hetero)arylthieno[3,2-b]pyridine-2-carboxylates
}

\section{Bruna R. Silva, ${ }^{\text {a,b,c }}$ Cristina P. R. Xavier, ${ }^{b, c}$ M. Helena Vasconcelos, ${ }^{b, c, d}$ Maria-João R. P. Queiroz ${ }^{a}$}

a Centre of Chemistry, University of Minho, Campus de Gualtar, 4710-057 Braga; bi3S - Instituto de Investigaçẫo Inovação em Saúde, Universidade do Porto, Portugal; ; Cancer Drug Resistance Group, IPATIMUP - Institute of Molecular Pathology and Immunology of the University of Porto, Portugal; ¿ Department of Biological Sciences, FFUP - Faculdade de Farmácia da Universidade do Porto, Portugal.

\section{INTRODUCTION}

Recently, we have been interested in the synthesis of thieno[3,2-b]pyridine derivatives functionalized on the thiophene ring and in their potential antitumor activity ${ }^{1}$.

\section{CHEMISTRY}

Herein, by C-C Pd-catalyzed Suzuki-Miyaura cross-coupling of methyl 3-bromothieno[3,2-b]pyridine-2-carboxylate with (het)aryl pinacol boranes, trifluoro potassium boronate salts or boronic acids, novel methyl 3(hetero)arylthieno[3,2-b]pyridine-2-carboxylates $1 \mathrm{a}-1 \mathrm{~h}$ were synthesized in moderate to high yields after column chromatography (Scheme 1), and were fully characterized by:

- ${ }^{\mathbf{H}} \mathbf{H}$

- ${ }^{13} \mathrm{C}-\mathrm{NMR}$

- HRMS

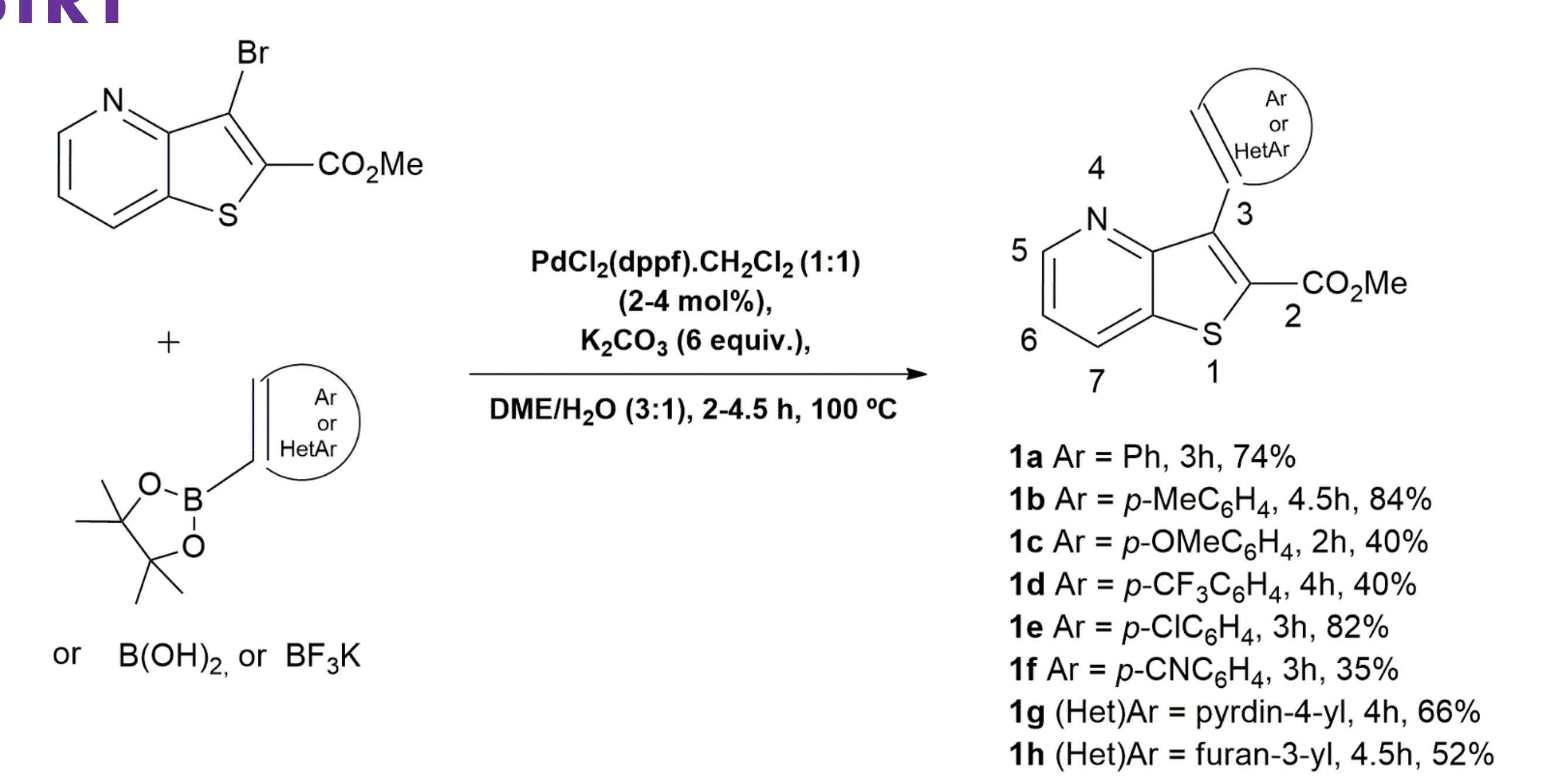

Scheme1. Synthesis of novel methyl 3-(het)arylthieno[3,2-b]pyridine-2-carboxylates by Scheme1. Synthesis of novel methy

\section{MATERIALS AND METHODS}

Sulforhodamine B (SRB) assay was used to screen 8 synthetized compounds (48h treatments) against different cancer cell line models - pancreatic adenocarcinoma (PANC-1 and BxPC3), nonsmall cell lung cancer ( $\mathrm{NCl}-\mathrm{H} 460)$ and triple negative breast cancer (MDA-MB-231 and MDA-MB-468). The cytotoxicity of the best compounds against the non-tumorigenic cell line MCF-12A was also evaluated by SRB

Trypan Blue Exclusion Assay allowed to determine the number of viable cells

The effect of the selected compounds on cell cycle profile was evaluated using Flow Cytometry with Propidium lodide

The expression of specific proteins was analysed by Western blot

Chick Chorioallantoic Membrane (CAM) assay was performed to evaluate the angiogenesis and/or tumorigenesis

RESULTS AND DISCUSSION

Table 1 - Gl $I_{50}$ concentrations $(\mu \mathrm{M})$ for each compound in different human tumor cell lines, using SRB the assay.

\begin{tabular}{|c|c|c|c|c|c|}
\hline & PANC-1 & BxPC3 & $\underline{\mathrm{NCl}-\mathrm{H} 460}$ & MDA-MB-231 & MDA-MB-468 \\
\hline $1 \mathrm{a}$ & $>10$ & $>20$ & $>20$ & $>20$ & $>20$ \\
\hline $1 \mathbf{b}$ & $>10$ & $>10$ & $>10$ & $>10$ & $>10$ \\
\hline 1c & $>10$ & $>10$ & $>10$ & $>10$ & $>10$ \\
\hline 1d & $>50$ & $>30$ & $>30$ & $>10$ & $>30$ \\
\hline $1 \mathrm{e}$ & $>10$ & $>14$ & $>10$ & $12.56 \pm 1.88$ & $>14$ \\
\hline If & $>50$ & $>30$ & $>50$ & $28.67 \pm 1.34$ & $8.73 \pm 1.73$ \\
\hline $1 \mathrm{~g}$ & $>50$ & $>75$ & $>75$ & $>75$ & $>75$ \\
\hline 1h & $>50$ & $>75$ & $>75$ & $>75$ & $4.67 \pm 0.68$ \\
\hline
\end{tabular}

Table 2 - Evaluation of the toxicity of the most promising compounds in the non-tumorigenic cell line MCF-12A by SRB assay.

\begin{tabular}{|c|c|c|c|}
\hline Compound & $\begin{array}{l}\mathrm{G}_{\mathrm{I}_{5}} \text { concentration } \\
(\mu \mathrm{M}) \text { in the tumor } \\
\text { cell lines }\end{array}$ & $\begin{array}{l}\text { Tumor cell line } \\
\text { tested }\end{array}$ & $\begin{array}{l}\text { \% of MCF-12A Cell } \\
\text { Growth at GI } \\
\text { concentration }\end{array}$ \\
\hline $\begin{array}{c}\text { Compound 1e } \\
(p-C l)\end{array}$ & $12.56 \pm 1.88$ & MDA-MB-231 & $88.62 \pm 4.04$ \\
\hline $\begin{array}{l}\text { Compound if } \\
\text { (p-CN) }\end{array}$ & $8.73 \pm 1.73$ & MDA-MB-468 & $117.73 \pm 3.22$ \\
\hline $\begin{array}{l}\text { Compound ih } \\
\text { (furan) }\end{array}$ & $4.67 \pm 0.68$ & MDA-MB-468 & $82.13 \pm 4.78$ \\
\hline
\end{tabular}

$1 e \rightarrow$ lowest $\mathrm{GI}_{50}$ value for the MDA-MB-231 cells

- $1 \mathrm{f}$ and $\mathbf{1 h} \rightarrow$ very low $\mathrm{GI}_{50}$ values for MDA-MB-468 cells

1e, $1 \mathrm{f}$ and $\mathbf{1 h} \rightarrow$ none or little toxicity against MCF12-A cells

\section{CONCLUSIONS}

We found 3 compounds in this series $(\mathbf{1 e}, \mathbf{1 f}$ and $\mathbf{1 h})$ that were able to cause growth inhibition of TNBC cell lines at low $\mathrm{Gl}_{50}(5-13 \mu \mathrm{M})$ without showing much toxicity against a non-tumorigenic cel line. Compound 1e caused an induction of DNA damage and decreased tumor size in CAM assay. Compound $\mathbf{1 h}$ induced cell cycle arrest at G2/M phase with high expression of p21 in the cells ACKNOWLEDGMENTS
We thank the FCT Portugal for financial support to CQUM (UID/686/2018-2019)
and PTNMR also financed by Portugal2020.

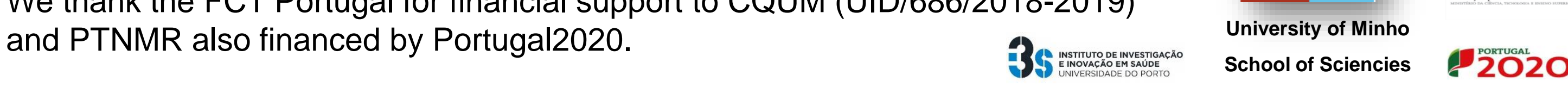
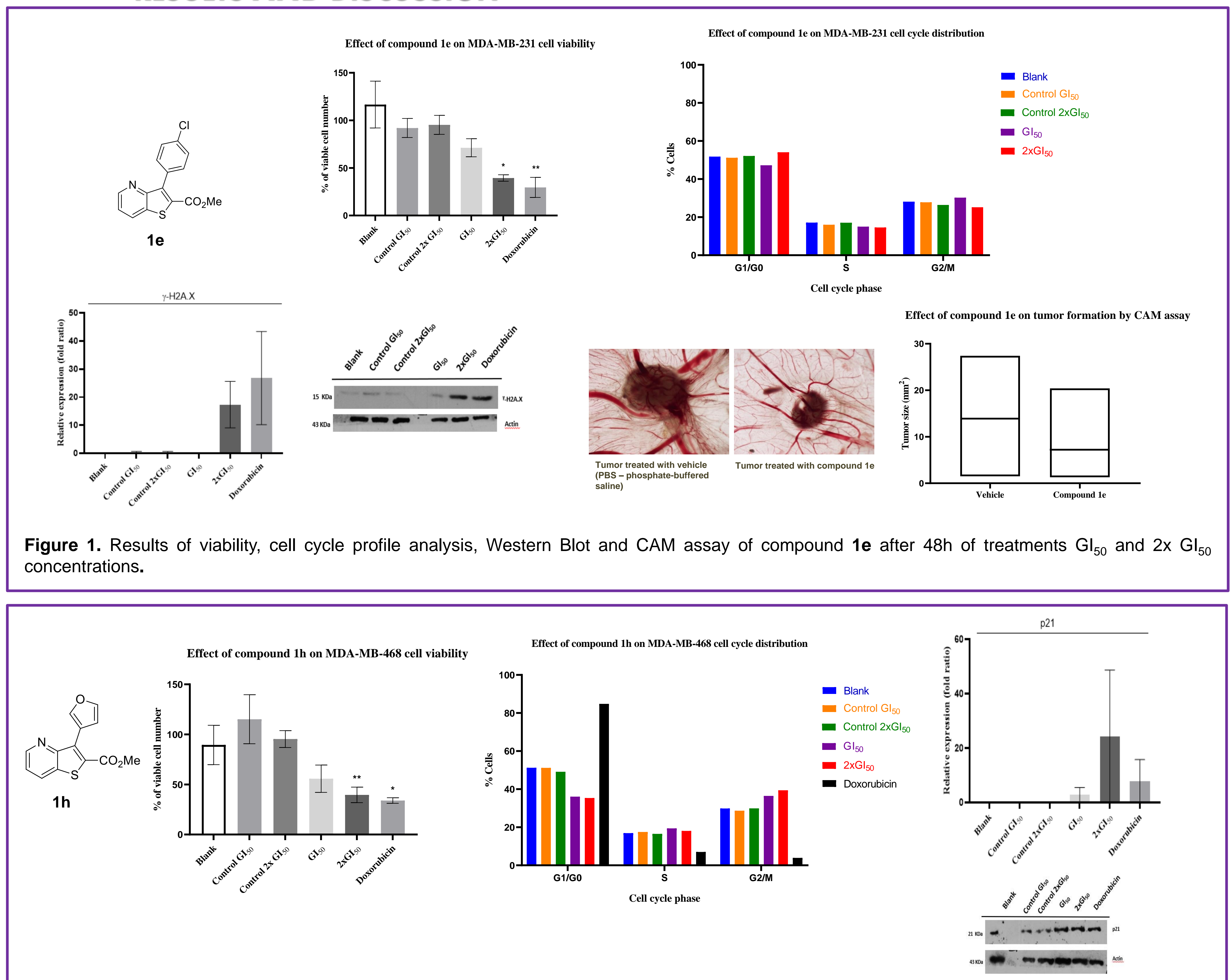

Figure 2. Results of viability, cell cycle profile analysis and Western Blot of compound $1 \mathrm{~h}$ after $48 \mathrm{~h}$ of treatments at $\mathrm{Gl}_{50}$ and $2 \times \mathrm{Gl}_{50}$ concentrations.

\footnotetext{
1e and $1 \mathrm{~h}$ decreased the number of viable cells at $2 \times \mathrm{Gl}_{50}$

1e seemed not to alter the cell cycle profile

1h increased G2/M phase with concomitant decrease of G1/G0

1e induced high expression of the DNA damage marker $y-H 2 A . X$ at $2 x \mathrm{Gl}_{50}$ concentration

1h presented high expression of the cell cycle marker p21

1e decreased the xenografted tumors size of the cells at $\mathrm{GI}_{50}$ concentration by the in ovo CAM assay
} 